\title{
A test of gamma-spectrometry in well-cuttings for paleoenvironmental and depositional studies on the Parque dos Gaviões Gas Field, Parnaíba Basin, Brazil.
}

Jeniffer Alves Nobre*, Antonio Fernando Menezes Freire, Cléverson Guizan Silva.

Universidade Federal Fluminense - UFF

Copyright 2019, SBGf - Sociedade Brasileira de Geofísica

This paper was prepared for presentation during the $16^{\text {th }}$ International Congress of the Brazilian Geophysical Society held in Rio de Janeiro, Brazil, 19-22 August 2019.

Contents of this paper were reviewed by the Technical Committee of the $16^{\text {th }}$ International Congress of the Brazilian Geophysical Society and do not necessarily represent any position of the SBGf, its officers or members. Electronic reproduction or storage of any part of this paper for commercial purposes without the written consent of the Brazilian Geophysical Society is prohibited.

\begin{abstract}
Present work consists in the measurement of the total and spectral gamma radiation of cutting samples from a well located at the Parque dos Gaviões Gas field, Parnaíba Basin, NE Brazil. Here, we propose to perform tests in the well 3-PGN-5-MA from three different acquisition times in order to evaluate the accuracy of measurements by comparing and calibrating with the total gamma ray curve acquired directly in the open hole. If we succeed with these measurements, an important working tool opens up, since it will be possible to have the spectral measurement of the natural radiation based on cutting samples, representing optimization especially in the initial phases of drilling, where logging is not performed in some cases, as well as promoting subsidies for paleoenvironmental discussions.
\end{abstract}

Keywords: Total and spectral GR; Parque dos Gaviões Gas Field; Parnaíba Basin; Depositional History.

\section{Introduction}

The Parnaíba Basin developed over a continental basin during the Stabilization Stage of the South American Platform (Vaz et al., 2007, apud Almeida and Carneiro, 2004). It is assumed that the substrate of this basin consists of metamorphic rocks, igneous and sedimentary, whose ages cover a long interval - from the Archaean to the Ordovician; however, rocks formed between the end of the Proterozoic and the beginning of the Paleozoic period, which corresponds to the time of consolidation of this platform, may predominate.

The sedimentary succession of the Parnaíba Basin can be divided in five supersequences: Silurian, Middle Devonian - Lower Carboniferous, Upper Carboniferous Lower Triassic, Jurassic and Cretaceous, which are delimited by unconformities that extend across the basin. In the context of the South American Platform, the first three sequences are in the Stadium of Stabilization and disagreements concerning it have their genesis in part related to fluctuations in the high eustatic epicontinental sea levels during the Lower Paleozoic. The transgressions came from the ocean adjacent to the southwest margin the Gondwana and from the paleo
Tethys Ocean (Vaz et al., 2007). Successive transgression-regression cycles along the geologic time could cause the input of different types of organic material. These organic matters can be identified by gamma spectrometry, since that different types of organic matter have different radioactive isotope contents.

The gamma spectrometry is the study of the natural gamma radiation emitted from a formation volume, through the natural radioactive decay of the source elements, mainly the uranium, thorium and potassium isotopes, respectively the isotopes $\mathrm{U}^{238}, \mathrm{Th}^{232}$ and $\mathrm{K}^{40}$. These are the most common elements and make up the predominant records of radioactivity in rocks (Faure, 1986, apud Ferreira et al., 2010). The variations between the spectral components of the gamma rays express the different proportions in which the concentrations of the elements $\mathrm{U}$, Th and $\mathrm{K}$ occurred. These elements, in the isotopic form, allow to characterize the different geochemical environments to which they were submitted, controlled by processes depositions.

Individually, the thorium element is diagnostic of oxygenated environments and its origin is related to rocks from source areas where felsic compositions predominate, mainly in high grade metamorphic rocks, and to a lesser extent in igneous rocks. The significance in discriminating the Th spectrum is shown when one wants to record events in higher depositional energy media, or subaerial exposure (Adams and Weaver, 1958). Potassium is related to the formation of clays, and its accumulation in low energy environment (Davies and Elliott, 1996). On the other hand, the higher presence of uranium is related to the concentration of organic matter, originated by the accumulation of organisms such as algae, bacteria and phytoplankton, common in lacustrine, lagoon and marine systems (Arthur, 1994). Thus, the study of gamma radiation, through geophysical measurements made with gamma spectrometers, allows, among other information, to identify the depositional environments and the paleoenvironmental conditions by which these rocks were submitted.

The main objective of this study is to calibrate the use of gamma spectrometry measurements direct from wellcuttings for the understanding of the paleoenvironmental and the depositional settings of the Parnaíba Basin, in particular in the area named Parque dos Gaviões Gas Field Area (Figure 1). The wells were gently provided by Parnaíba Gás Natural, compared to GR logs obtained from those well, gently provided by the Petroleum National Agency (ANP). 


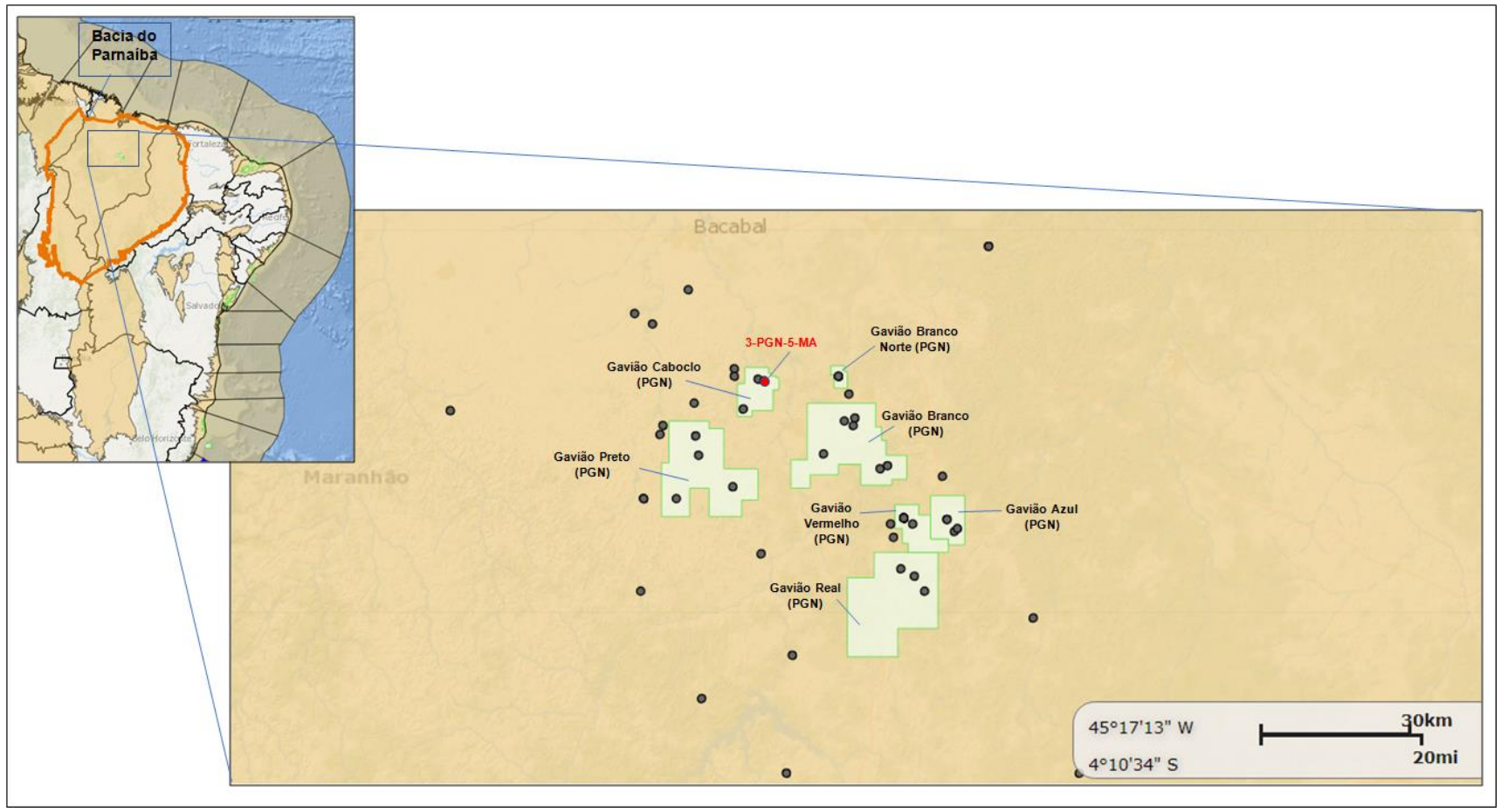

Figure 1: Location map of Parque dos Gaviões Gas Field, at Parnaíba Basin, NE Brazil. In detail is the well 3-PGN-5-MA. Source: http://webmaps.anp.gov.br/mapas.

In addition, this study plans to:

- Generate total gamma-spectrometer (GR) curves, as well as curves of $\mathrm{K}(\%), \mathrm{U}(\mathrm{ppm})$ and Th (ppm), based on measurements on cutting samples;

- Correlate and calibrate the Total GR curve with the GR curve (API) obtained through open well logging;

- To identify the spectrum (K-U-Th) that influence the measurements of Total GR and, through the study of these parameters and their ratios, to make paleoenvironmental inferences for the reconstruction of the depositional history of the study area;

- Develop working methodology for the use of gamma spectrometry measurements in cutting samples to aggregate spectral data to the GR curve (API) obtained in the wells;

- Make correlations between the wells that will be studied for the recognition of chemostatigraphic surfaces and for the application of sequence stratigraphy concepts.

\section{Method}

- Measure of an interval on cutting samples from the well 3-PGN-5-MA;

- Make spreadsheets, containing depth values, Total GR, $\mathrm{K}$, eU, eTh and ratios, measured using the Radiation Solutions Inc RS-230 BGO Super-SPEC Handheld Gamma-Ray Spectrometer;

- Import of these values into the Interactive Petrophysics (IP) software to generate GR, K (\%), eU (ppm) and eTh (ppm) curves, as well as eU/eTh, $\mathrm{K} / \mathrm{eU}$ and $\mathrm{K} / \mathrm{eTh}$;
- Correlate the curves generated with the GR curve (API) obtained during the open well logging, run after drilling.

- In a next step, to integrate and interpret these curves and their correlations, in light of the concepts of sequence stratigraphy, to infer a paleoenvironmental reconstruction and to suggest a depositional history for the filling of the Parnaíba Basin, in the study area.

\section{Preliminary Results}

This study in its initial phase and now we are performing tests about the best parameters to get measurements. The acquisition times used were $30 \mathrm{~s}, 60 \mathrm{~s}$ and $90 \mathrm{~s}$ for each cutting sample, performed in the interval of $1044 \mathrm{~m}$ to $1146 \mathrm{~m}$ of the well $3-P G N-5-M A$ totaling 35 cutting samples, which were collected in an interval of $3 \mathrm{~m}$. From the data obtained, we imported the curves for the IP software and compared each generated curve of Total GR (nGy/h), of the three different durations, with GR (API) in order to identify the best adjustment (Figure 2).

By means of the comparative evaluation between these curves, it was possible to infer that the Total GR (nGy/h) curves were with a downward shift in relation to the GR curve (API) and this can be explained by difference between log depths and drilling depths. Thus, an adjustment of the GR (API) curve was performed through the IP software (Figure 3 ) in order to visualize what we believe to be the corresponding depths. This procedure should be considered along the correlation between the GR curves. 


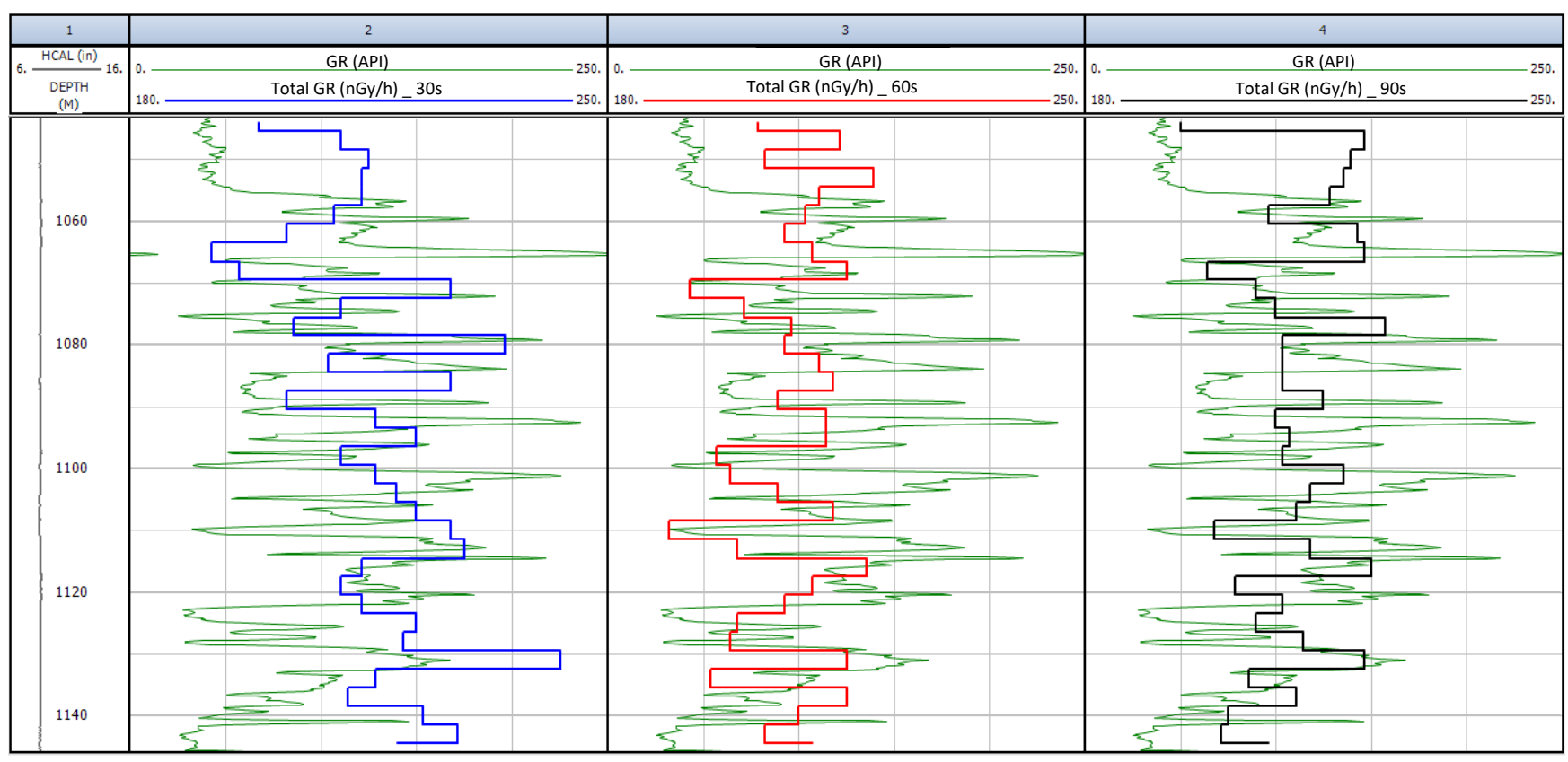

Figure 2: Total gamma ray curves: in green the Total GR curve of the well, in blue curve obtained by the Total GR using the gamma spectrometer RG-230, with acquisition time of 30s, in red with 60 s and in black with 90 s of duration.

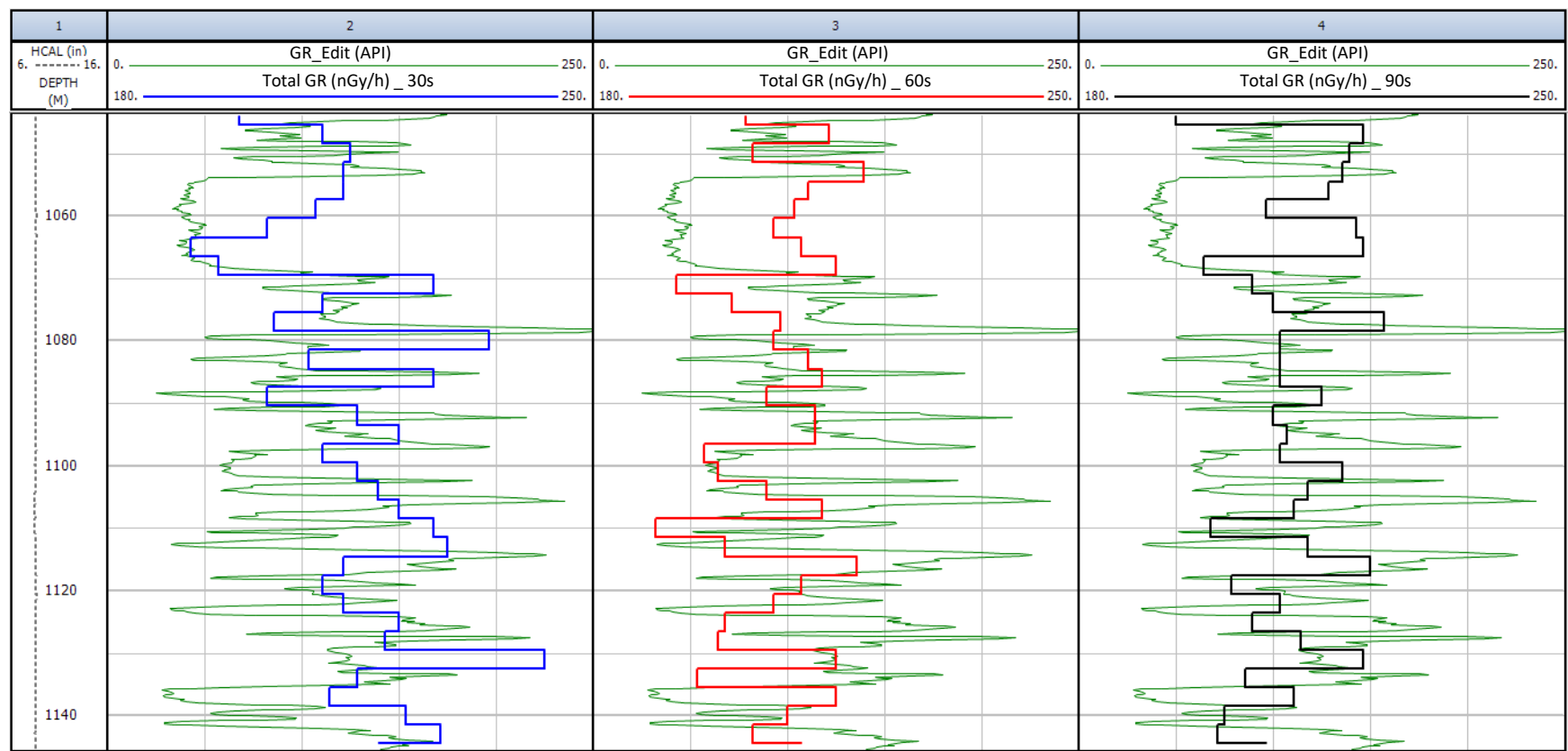

Figure 3: Adjustment on the depth of curves for a better correlation between cutting measurements Total GR (nGy/h) and Total GR (API) from open well logging. 
An important gain in the application of this technique is the measurement of spectral gamma radiation, absent in most of the gas wells drilled onshore, due to the high cost of acquisition. These measurements on the cutting samples, duly calibrated through the total GR count, will be used to carry out paleoenvironmental studies that will help to understand the depositional environments present in the study area.

Preliminary analyzes of the behavior of the $\mathrm{K}, \mathrm{U}$ and Th spectral curves as well as the U/Th ratio (Figure 4) allow the observation of cycles that need to be better interpreted in order to infer the depositional environments in the area of the Parque dos Gaviões. The study is ongoing.

\section{Preliminary Conclusions}

From the evaluation of the curves, we conclude that the 60 s time delivers a satisfactory result. It is possible to observe increasing and decreasing cycles of total gamma radiation which accompany the curve performed in the well. However, in other intervals there was no good correlation and this can be explained by the conditions of recovery of the cutting samples, such as their arrival time to surface and because they represent the average of a $3 \mathrm{~m}$ sedimentary package. In this way, we are looking for the best way to apply the tool and an appropriate processing. The acquired data and the method have shown to be promising since we will obtain four important geophysical data of the rocks, in addition, these curves will be fundamental mainly in intervals of the wells that were not realized the well logging acquisition.

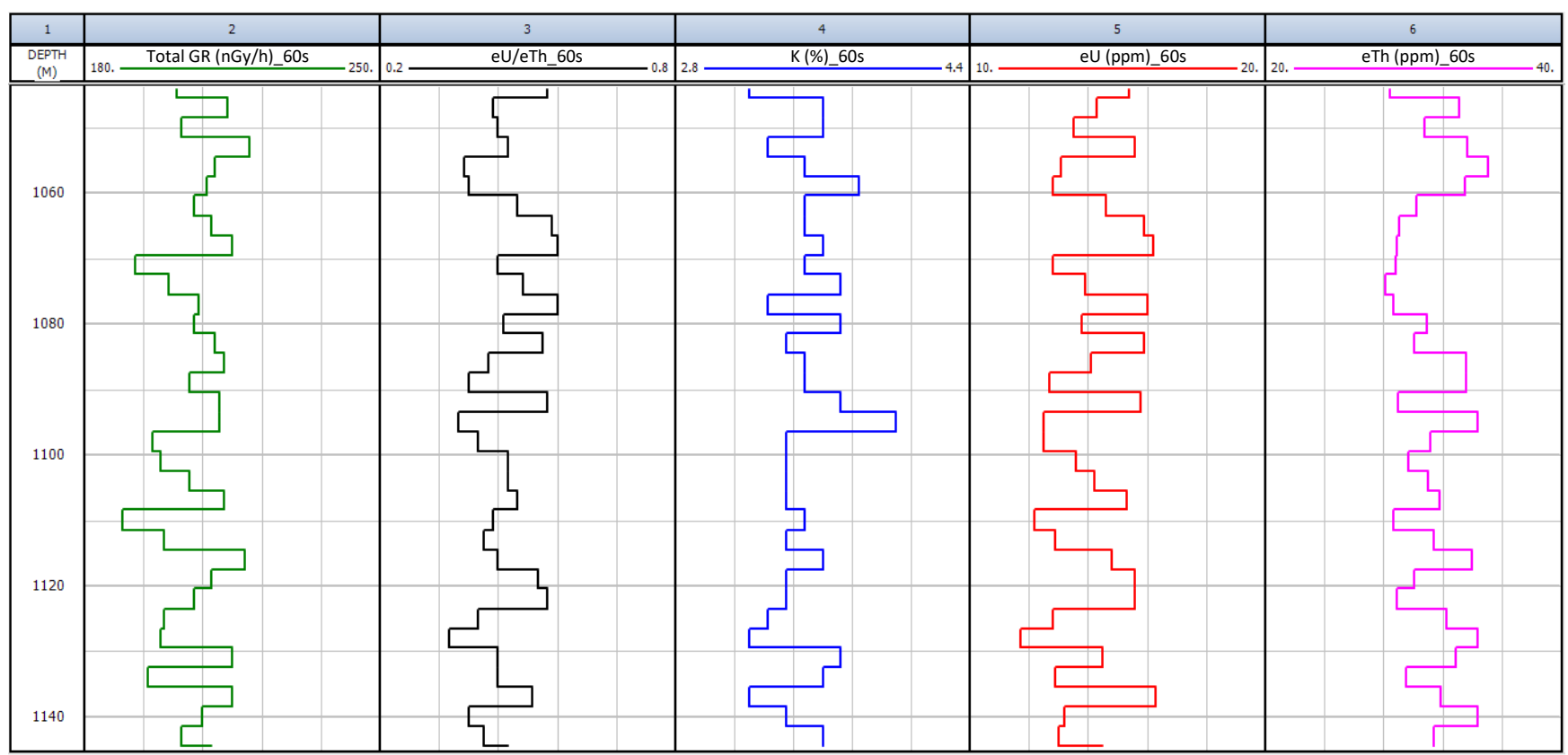

Figure 4: Curves display: track 1: Depth; track 2: Total GR (nGy/h); track 3: eU/eTh ratio; track 4: K (\%); track 5 eU (ppm); track 6: eTh (ppm). Al curves were measured using an acquisition time of $60 \mathrm{~s}$. 


\section{Acknowledgments}

To Parnaíba Gas Natural and ANP for providing well data to perform this work; to Lloyd's Register for the permission to use the software Interactive Petrophysics (IP).

\section{References}

Adams, J.A.S.; Weaver, C.E. Thorium-to-uranium ratios as indicators of sedimentary processes: Example of concept of geochemical facies. AAPG Bulletin, v. 42(2), p. 387-430, 1958.

Arthur, M.A. Marine Black Shales: Depositional mechanisms and environments of ancient deposits. Annu. Rev. Earth and Planetary Science, v.22, p. 499551, 1994.

Bristow, C.S.; Williamson, B.J. Spectral gamma ray logs: core to log calibration, facies analysis and correlation problems in the Southern North Sea. In: Harvey, P.K.; Lovell, M.A. (eds) Core-log integration. Geological Society of London, Special Publications, v.136, p. 1-7, 1998.

Brown, J.E.; Nikitin, A; Valetova, N.K.; Chumichev, V.B.; Katrich, I.Y.; Berezhnoy, V.I.; Pegoev, N.N.; Kabanov, A.I.; Pichugin, S.N.; Vopiyashin, Y.Y.; Lind, B.; Grotthein, S.; Sickel, M.; Strand, P. Radioactive contamination in the marine environment adjacent to the outfall of the radfioactive waste treatment plant at ATOMFLOT, northern Russia. Journal of Environmental Radioactivity, Elsevir, v. 61, p. 111-131, 2002.

Davies, S.J.; Elliott, T. Spectral gamma ray characterization of high resolution sequence stratigraphy: examples from Upper Carboniferous flúvio-deltaic systems, County Clare, Ireland. In: Howell, J.A.; Aitken, J.F. (eds) High resolution sequence stratigraphy: Innovations and applications. Geological Society of London, Special Publications, v.104, p. 25-35, 1996.

Ferreira, Francisco José Fonseca, Ary Gustavo Candido, and Sidnei Pires Rostirolla. "Correlação gamaespectrométrica de afloramento e poços: estudo de caso na Formação Ponta Grossa (Bacia do Paraná, Brasil)." Revista Brasileira de Geofisica 28.3 (2010): 371-396.

Hampson, G.J.; Davies, W.; Davies, S.J.; Howell, J.A.; Adamson, K.R. Use of spectral gamma-ray data to refine subsurface fluvial stratigraphy: Late Cretaceous strata in the Book Cliffs, Utah, USA. Journal of the Geological Society, v.162, p. 603-621, 2005.
Jones, D.G. Development and application of marine gamma-ray measurements: a review. Journal of Environmental Radioactivity, v. 53, p. 313-333, 2001.

Ulbrich, Horstpeter Herberto Gustavo José, et al. "Levantamentos gamaespectrométricos em granitos diferenciados. I: revisão da metodologia e do comportamento geoquímico dos elementos $\mathrm{K}$, Th $\mathrm{e}$ U." (2009).

Vaz, P.T.; Rezende, N.G.A.M.; Wanderley Filho, J.R.; Travassos, W.A.S. Bacia do Parnaíba. Boletim de Geociências da Petrobras, v.15(2), p.253-263, 2007. 